\title{
Kewajiban Pengusaha Dalam Pemberian Upah Minimum Pekerja Pasca Putusan Mahkamah Konstitusi Nomor : 72/PUU-XIII/2015
}

Oleh:

\author{
Griselda Nadya Billy* \\ Ibrahim $\mathrm{R}^{* *}$ \\ Program Kekhususan Hukum Bisnis Fakultas Hukum \\ Universitas Udayana
}

\begin{abstract}
ABSTRAK
Penangguhan pembayaran upah minimum berdasarkan Pasal 90 ayat (2) Undang-Undang Republik Indonesia Nomor 13 Tahun 2003 tentang Ketenagakerjaan menjelaskan bahwa akan memberikan kesempatan kepada perusahaan untuk tidak membayar upah minimum dalam kurun waktu tertentu. Namun, dalam Pasal 90 ayat (1) menjelaskan pengusaha dilarang membayar upah lebih rendah dari upah minimum. Artinya ketentuan tersebut melemahkan perlindungan hukum dari Pasal 90 ayat (1). Tujuan dari penelitian ini adalah untuk lebih memahami penangguhan pembayaran upah minimum tersebut dapat menghilangkan apa yang menjadi kewajiban pengusaha agar dapat membayar selisih upah minimum kepada pekerja. Metode penelitian yang digunakan adalah penelitian hukum normatif yang menggunakan pendekatan perundang-undangan dan pendekatan konseptual. Sumber bahan hukum yang digunakan berupa bahan hukum primer, sekunder, dan tersier. Dalam Undang-Undang Republik Indonesia Nomor 13 Tahun 2003 tentang Ketenagakerjaan penangguhan pembayaran upah minimum menghilangkan apa yang menjadi kewajiban pengusaha untuk dapat membayar selisih upah minimum selama masa penangguhan sesuai dengan Putusan Mahkamah Konstitusi Nomor : 72/PUU-XIII/ 2015.
\end{abstract}

Kata Kunci : Upah, Pekerja

* Griselda Nadya Billy, adalah Mahasiswa Fakultas Hukum Universitas Udayana, nadyabilly27@yahoo.com

** Ibrahim R, adalah Dosen Pengajar Hukum Administrasi Negara Fakultas Hukum Universitas Udayana, sebagai penulis kedua. 


\begin{abstract}
The suspension of minimum wage payment based on Article 90 Paragraph (2) of the law of the Republic of Indonesia Number 13 Year 2003 about Employment explains that it will give an opportunity for the company not to pay minimum wage within a certain period of time. However, Article 90 paragraph (1) explains that employers are prohibited from paying wages lower than the minimum wage. This means that the provision undermines the legal protection of Article 90 paragraph (1). The purpose of this study is to better understand the suspension of payment of minimum wage can eliminate the obligation of employers to pay the minimum wage difference to workers. The research method used is normative legal research with the approach of legislation and concepual approach. Sources of legal materials used in form of primary, secondary, and tertiary legal materials. In the Law of the Republic of Indonesia Number 13 Year 2003 regarding Employment suspension of minimum wage payment does not eliminate the obligation of employers to pay the minimum wage difference during the period of suspension in accordance with the Constitutional Court Decision Number : 72/PUU-XIII/2015.
\end{abstract}

\title{
Keywords: Wage, Workers.
}

\section{Pendahuluan}

\subsection{Latar Belakang}

Manusia dalam memenuhi kehidupannya berusaha untuk memenuhi segala kebutuhannya dengan beragam variasi yang relatif tergantung pada kemampuan atau daya beli seseorang. Berdasarkan ketentuan dalam Pasal 1 angka 3 Undang-Undang Nomor 13 Tahun 2003 tentang Ketenagakerjaan ( selanjutnya disebut UU Ketenagakerjaan ) menjelaskan pekerja atau buruh merupakan setiap orang yang bekerja dengan menerima upah atau imbalan dalam bentuk lain. Salah satu yang menjadi kewajiban seorang majikan, pengusaha, atau pemberi kerja, yaitu dengan memberikan upah kepada pekerja tepat pada waktunya. 
Sedangkan dalam Pasal 1 angka 30 UU Ketenagakerjaan menjelaskan bahwa upah merupakan hak para pekerja yang diterima sebagai imbalan dalam bentuk uang dari pengusaha atau pemberi kerja yang dibayarkan sesuai dengan perjanjian kerja yang telah disepakati atau peraturan perundang-undangan. Agar menyetarakan standar upah demi memberikan penghidupan yang layak bagi pekerja, maka pemerintah menetapkan upah minimum yang mana terhadap upah minimum tersebut berbeda-beda pada setiap daerah. Upah minimum sifatnya wajib tanpa pilihan lain. Yang artinya pemerintah menyatakan bahwa pengusaha dilarang membayar upah di bawah upah minimum yang telah ditentukan.

Pada kenyataannya, Kapasitas modal dan produksi setiap perusahaan tidaklah sama. Ada perusahaan yang bermodal besar dengan daya dukung teknologi modern dan manajemen yang handal dan adapun perusahaan yang bermodal kecil dengan daya dukung teknologis yang tidak memadai. Sehingga tidak semua pengusaha atau pemberi kerja mampu untuk memberikan upah minimum yang telah di tentukan oleh pemerintah tersebut. Sehingga perusahaan dapat melakukan penangguhan pembayaran upah minimum.

Penangguhan pembayaran upah minimum berdasarkan Pasal 90 ayat (2) UU Ketenagakerjaan, bahwa perusahaan yang mana dikatakan tidak mampu untuk membayar upah dapat diberikan kesempatan untuk tidak membayar membayar upah minimum dalam kurun waktu tertentu. Namun pada Pasal 90 ayat (1) menjelaskan Pengusaha dilarang membayar upah lebih rendah dari upah minimum.

Pada Pasal 90 ayat (1) ketentuan a-quo dimaksud untuk memberikan perlindungan dan penghidupan secara layak pada buruh. Secara implisit dalam arti melindungi pekerja, sehingga 
tidak terdapat pengecualian atau memperbolehkan seorang pengusaha untuk membayar dibawah Upah Minimum. Sebaliknya dalam Pasal 90 ayat (2) terdapat pengecualian bagi pengusaha yang tidak mampu membayar upah minimum tersebut sehingga tujuan dari Pasal 90 ayat (1) tersebut dilemahkan. Selanjutnya dikatakan dalam Pasal 28D ayat (2) Undang-Undang Dasar Negara Republik Indonesia Tahun 1945 yang mengartikan bahwa setiap orang berhak mendapatkan pekerjaan yang layak pada setiap perusahaan yang tentunya orang tersebut mempunyai hak mendapatkan imbalan yang adil dan sesuai dengan tanggung jawabnya. Prinsip yang terkandung dalam ketentuan konstitusional diatas berkaitan dengan upaya perlindungan bagi tenaga kerja dimaksudkan untuk menjamin hak-hak dasar pekerja/buruh dan menjamin kesamaan kesempatan serta perlakuan tanpa diskriminasi atas dasar apapun untuk mewujudkan kesejahteraan buruh dan keluarganya dengan tetap memperhatikan perkembangan kemajuan dunia usaha. ${ }^{1}$ Sehingga kebijakan penangguhan upah melahirkan ketidakpastian terhadap upah minimum yang ditetapkan pemerintah dengan tujuan untuk memberikan penghidupan yang layak kepada pekerja.

Beberapa hasil terdahulu mengatur mengenai Kewajiban Pengusaha dalam Pemberian Upah Minimum terhadap pekerja menurut Henny Damaryanti,2017, "Pemenuhan Upah Minimum Sebagai Upaya Perlidungan Hak Konstitusional”, Jurnal Fakultas Hukum Universitas Panca Sakti,Pontianak yaitu diantara nya bahwa upah didefinisikan sebagai harga atas pekerjaan yang dijadikan dasar penetapan standar upah minimum dengan

1 I Made Udiana, 2016, Kedudukan dan Kewenangan Pengadilan Hubungan Industrial, Udayana University Press, Denpasar, h.4 
harapan setiap tenaga kerja terpenuhi kebutuhan hidupnya secara layak berdasarkan upah yang diperolehnya.

Berdasarkan hal tersebut maka penulis akan mengkaji analisa yang berjudul "PENGARUH PENANGGUHAN PEMBAYARAN UPAH MINIMUM TERHADAP KEWAJIBAN PENGUSAHA DALAM MEMBERIKAN UPAH KEPADA PEKERJA ATAU BURUH".

\subsection{Rumusan Masalah}

Dengan adanya latar belakang tersebut penulis mengangkat rumusan masalah sebagai berikut :

1. Bagaimanakah hubungan hukum pengusaha dan pekerja atau buruh?

2. Apakah penangguhan pembayaran upah minimum dapat dikatakan menghilangkan kewajiban dari pengusaha untuk membayar selisih upah minimum dengan pembayaran yang dilakukan oleh pengusaha selama masa penangguhan?

\subsection{Tujuan}

Tujuan penulisan jurnal ilmiah ini dimaksudkan agar lebih memahami mengenai penangguhan pembayaran upah minimum tersebut dapat menghilangkan suatu kewajiban seorang pengusaha untuk tetap membayar selisih upah minimum kepada para buruh.

\section{Isi Makalah}

\subsection{Metode Penelitian}

\subsubsection{Jenis Penelitian}


Penulis menggunakan penelitian normatif yang terdapat hubungan langsung terhadap praktik hukum dari dua aspek utama, yaitu berkaitan dengan pembentukan hukum dan penerapan hukum. ${ }^{2}$ Penelitian normatif juga dapat dikatakan sebagai penelitian perpustakaan karena mengkaji data sekunder melalui keputusan pengadilan, teori hukum, dan menggunakan analisis kualitatif. Penelitian hukum normatif menitikberatkan pada inventarisasi atau tindakan hukum positif, asas-asas dan doktrin hukum, penemuan hukum perkara In Concreto, sistematik hukum, taraf sinkronisasi, perbandingan hukum dan sejarah hukum. ${ }^{3}$

\subsubsection{Jenis Pendekatan}

Pada penulisan jurnal ilmiah ini penulis menggunakan pendekatan perundang-undangan dan pendekatan konseptual. Pendekatan perundang-undangan merupakan pendekatan yang menelaah isu hukum dengan mempelajari konsistensi dan kesesuaian dari suatu undang-undang atau Undang-Undang Dasar. 4

\subsubsection{Bahan Hukum}

Berikut adalah bahan hukum yang dipergunakan dalam jurnal ilmiah ini yaitu :

1. Bahan hukum primer, yaitu bahan hukum yang bersifat kekuasaan yang sah atau otoritas yaitu UUD NRI 1945 dan Undang-Undang Ketenagakerjaan.

2 Johnny Ibrahim, "Teori dan Metode Penelitian Hukum Normatif," Cet. 1 Malang : Bayumedia Publishing,2005, h.46

${ }^{3}$ Abdullkadir Muhamad. 2004, Hukum dan Penelitian Hukum, Cet. 1. Bandung : PT. Citra Aditya Bakti, h. 52

4 Peter Mahmud Marzuki, 2005, Penelitian Hukum, Kencana Prenadamedia Group, Jakarta, h.133 
2. Bahan hukum sekunder, yaitu semua publikasi hukum yang terdiri atas rancangan hasil penelitian, buku teks yang memuat prinsip dan pandangan para ahli hukum, tulisantulisan atau hasil karya tentang hukum.

3. Bahan hukum tersier, yaitu bahan yang memberikan petunjuk dan penjelasan terhadap bahan hukum primer dan sekunder yang memberikan penjelasan bahan hukum lainnya yaitu surat kabar, kamus hukum, dan kamus Besar Bahasa Indonesia.

\subsubsection{Teknik Pengumpulan Bahan Hukum}

Dalam jurnal ilmiah ini menggunakan penelitian normatif , teknik pengumpulan bahan hukum menggunakan studi kepustakaan dengan mengkaji peraturan perundang-undangan. Dengan mencari bahan-bahan hukum dalam buku yang terkait dengan permasalahan kemudian dikutip bagian penting dan disusun secara sistematis sesuai dengan pembahasan dalam penelitian ini.

\subsubsection{Teknik Pengolahan Bahan Hukum}

Dalam analisis penelitian normatif ini menggunakan sumber penelitian nya yaitu merumuskan dasar-dasar hukum, merumuskan pengertian hukum, merumuskan kaidah-kaidah hukum, pembentukan standar-standar hukum.

\subsection{Hasil Analisa}

\subsubsection{Hubungan Hukum Pengusaha dan Pekerja atau Buruh}

Hubungan Hukum atau yang disebut dengan Rechtsbetrekking merupakan hubungan yang terkait antara 2 subyek hukum atau lebih dimana salah satu pihak hak dan kewajibannya berhadapan dengan hak dan kewajiban dipihak lain. Berdasarkan sifat hubungannya, hubungan hukum terbagi 
menjadi 2 jenis yaitu jenis hubungan hukum timbal balik dan hubungan hukum timpang. Dalam hal hubungan hukum timbal balik para pihak sama-sama mempunyai hak dan kewajiban yang harus dipenuhi dan terpenuhi, sedangkan hubungan hukum timpang dimaksudkan bahwa salah satu pihak hanya mempunyai hak dan pihak lain yang terikat mempunyai kewajiban.

Menurut Imam Soepomoe, hubungan kerja merupakan suatu hubungan antara seorang buruh dan seorang majikan, di mana hubungan kerja itu terjadi setelah adanya perjanjian kerja antara kedua pihak. Di satu pihak pekerja bersedia bekerja dengan menerima upah dan pengusaha mempekerjakan pekerja dengan memberi upah. ${ }^{5}$ Dalam Undang-Undang Nomor 13 Tahun 2003 tentang Ketenagakerjaan Bab IX pasal 50 - pasal 66.

Hubungan antara pengusaha dan pekerja atau buruh bersifat subordinasi diatur dalam ketentuan KUHPerdata Pasal 1601a. Perjanjian Kerja merupakan dimana pihak pekerja mengikatkan dirinya pada pihak lain dan pihak majikan menyatakan kesanggupannya untuk mempekerjakan pekerja dengan membayar upah. Unsur upah adalah adanya upah tertentu yang menjadi imbalan atas pekerjaan yang dilakukan oleh pekerja/buruh. Terdapat juga unsur perintah atau yang disebut dengan gezag ver houding yang artinya dibawah perintah, dimana dalam suatu hubungan kerja kedudukan majikan sebagai pemberi kerja berhak dan berkewajiban untuk memberikan perintahperintah yang berkaitan dengan pekerjaannya tersebut. Dalam Undang-Undang Ketenagakerjaan tidak mengatur secara eksplisit mengenai pekerjaan yang diperjanjikan kecuali pekerjaan yang diperjanjikan dengan Perjanjian kerja waktu tertentu.

${ }^{5}$ Zaeni Asyhahadie, 2007, Hukum Kerja: Hukum Ketenagakerjaan Bidang Hubungan Kerja, PT. Raja Grafindo Persada, Jakarta, h.3. 
Hubungan hukum antara pekerja/buruh dengan pengusaha diatur oleh otonom yang artinya ketentuan yang dibuat oleh pekerja/buruh dan pengusaha sendiri, juga diatur oleh hukum heteronom yang artinya ketentuan yang dibentuk atau dibuat oleh pembentuk undang-undang. ${ }^{6}$

Perjanjian kerja haruslah terwujud karena adanya itikad baik dari para pihak, yang mana didalamnya terkandung hak dan kewajiban dari para pihak, maka untuk itu perlu dibuatnya perjanjian untuk mencerminkan keadilan bagi para pihak. ${ }^{7}$ Hak pekerja merupakan sesuatu yang diberikan kepada seseorang atas kedudukan atau statusnya, adapun hak-haknya, yaitu : Hak mendapat upah atau gaji yang diatur dalam Pasal 1602 KUHPerdata, Pasal 88 s/d Pasal 97 Undang-Undang Ketenagakerjaan; Hak atas pembinaan keahlian kejuruan dalam memperoleh dan menambah keahlian keterampilan, diatur dalam Pasal 9/d Pasal 30 Undang-Undang Ketenagakerjaan; Sedangkan Kewajiban dari Pekerja berdasarkan Undang-Undang Ketenagakerjaan, terdapat pada Pasal 102 ayat (2), Pasal 126 ayat (1) dan ayat (2), Pasal 136 ayat (1), dan Pasal 140 ayat (1) yang menguraikan bahwa tugas utama dari seorang pekerja adalah wajib melakukan pekerjaan nya sendiri, wajib menaati peraturan dan petunjuk pengusaha, wajib membayar ganti rugi dan denda, wajib menjaga rahasia perusahaan, wajib memenuhi seluruh

${ }^{6}$ Fenny Natalia Khoe, 2013, "Hak Pekerja Yang Sudah Bekerja Namun Belum Mendatangani Perjanjian Kerja Atas Upah Ditinjau Berdasarkan UndangUndang Nomor 13 Tahun 2003 Tentang Ketenagakerjaan”, Jurnal Fakultas Hukum Universitas Surabaya, Surabaya.

7 G. Kartasapoetra, R.G Kartasapoetra, dan A.G Kartasapoetra, 1994, Hukum Perburuhan Di Indonesia Berdasarkan Pancasila, Cet. IV, Sinar Grafika, Jakarta, h. 64. 
kewajiban selama izin belum diberikan dalam hal banding yang belum ada putusannya. ${ }^{8}$

Tidak selamanya kehadiran penanam modal asing di Indonesia memberikan pengaruh positif. ${ }^{9}$ Adapun hak pengusaha sebagai berikut: berhak menetapkan mulainya istirahat tahunan dengan memperhatikan kepentingan buruh (Pasal 5 ayat (1) PP No.21 Tahun 1954), berhak mendapatkan pelayanan agar memperoleh calon buruh dari Indonesia yang nantinya akan diberangkatkan ke luar negeri dari Kandepnaker, berhak menjatuhkan denda yang telah diatur tegas atas pelanggaran dalam suatu perjanjian tertulis perusahaan (Pasal 20 ayat (1) PP No.8 Tahun 1981), Dapat meminta ganti rugi jika terjadi kerugian atau kerusakan milik perusahaan baik sengaja atau kelalaian (Pasal 23 ayat (1) PP No.8 Tahun 1981). Adapun kewajiban dari pengusaha adalah memberikan prestasi atas kepentingan pekerja. Kewajiban pengusaha, yaitu : Wajib membayar upah tepat waktu sesuai dengan perjanjian yang ditentukan, diatur dalam Pasal 10 ayat (1) Peraturan Pemerintah Nomor 8 Tahun 1981; Wajib menjaga agar tidak terjadi pemutusan hubungan kerja; wajib memberikan keterangan yang diminta oleh pejabat yang berwenang; wajib memberikan istirahat atau cuti; Wajib mengurus perawatan dan pengobatan.

\subsubsection{Pengaruh Penangguhan Pembayaran Upah Minimum Terhadap Kewajiban Pengusaha untuk Membayar Selisih Upah Minimum Selama Masa Penangguhan.}

\footnotetext{
8 Ikhwan Fahrojih, 2016, Hukum Perburuhan, Setara Press, Jawa Timur, h. 40 .

9 I Made Udiana, 2011, Rekonstruksi Pengaturan Penyelesaian Sengketa Penanaman Modal Asing, Udayana University Press, Denpasar, h.3.
} 
Secara umum upah minimum di bagi menjadi dua kategori yaitu Upah Minimum Provinsi (selanjutnya disebut UMP) dan Upah Minimum Kabupaten (selanjutnya disebut UMK). Upah tersebut bertujuan sebagai jaring pengaman atau safety net agar pekerja atau buruh tidak di ekploitasi dan mendapatkan kehidupan yang layak bagi diri dan keluarganya.

Pada kenyataan kehidupan para buruh jaman sekarang sebagaimana Gubernur menetapkan pembayaran upah setiap tahunnya tidak menguntungkan buruh khususnya yang bekerja disektor informal seperti Pegawai Negeri Sipil. Ini disebabkan karena pembayaran upah atau gaji yang tidak sesuai dengan standar dalam UU Ketenagakerjaan. Dalam pasal 90 ayat (1) UU Ketenagakerjaan menjelaskan bahwa ada ketidaksesuaian upah buruh dengan standar UMP dan UMK. Kondisi seperti ini merugikan pihak buruh dan keluarganya untuk memenuhi kehidupannya baik berupa makanan, sandang, pendidikan, kesehatan, maupun jaminan hari tua. Sebagian besar posisi pengusaha bertujuan mengejar laba semata-mata tanpa memikirkan penghidupan buruh dan keluarganya.

Ketentuan Pasal 88 ayat (1) UU Ketenagakerjaan dikatakan bertentangan mengenai pembayaran upah buruh dibawah upah minimum yang menjelaskan bahwa pekerja mempunyai hak untuk mendapat penghasilan yang memenuhi kehidupan layak bagi kemanusiaannya.

Faktanya tidak semua pengusaha dapat memberikan upah yang sesuai dengan standar upah minimum, sehingga adanya penangguhan pembayaran upah minimum bertujuan untuk memberikan perlindungan terhadap para pekerjanya. Penangguhan pembayaran upah minimum bagi pengusaha agar dapat memberikan kesepatan kepada pengusaha untuk membayar 
upah sesuai dengan kurun waktu yang ditentukan. Sedangkan bagi pekerja penangguhan pembayaran upah minimum memberikan perlindungan untuk tetap bekerja dan kepastian hukum dalam hubungan kerja.

Berdasarkan ketentuan Pasal 90 ayat (1) UU Ketenagakerjaan secara implisit memberikan perlindungan kepada pekerja dalam hal penerimaan upah, yang mana pengusaha tidak diperbolehkan membayar upah lebih rendah dari upah minimum. Sedangkan jika meninjau dari Pasal 90 ayat (2) UU Ketenagakerjaan memberikan pengecualian terhadap Pasal 90 ayat (1), jika terdapat pengusaha yang tidak mampu membayar upah minimum tersebut maka dapat dilakukan penangguhan pembayaran upah minimum yang lebih lanjut diatur dalam Keputusan Menteri Tenagakerja dan Transmigrasi Republik Indonesia Nomor: KEP.231/MEN/2002 Tentang Tata Cara Penangguhan Pelaksanaan Upah Minimum.

Selanjutnya dijelaskan dalam ketentuan Pasal 90 ayat (2) bahwa bagi perusahaan yang tidak mampu akan dilakukan penangguhan pelaksanaan upah minimum bertujuan untuk memberikan kesempatan pada perusahaan yang bersangkutan membayar upah minimum yang berlaku dalam kurun waktu tertentu. Jika dikatakan penangguhan tersebut berakhir maka perusahaan tersebut wajib melaksanakan upah minimum pada saat itu tetapi tidak diwajibkan membayar pemenuhan ketentuan upah minimum yang berlaku pada waktu diberikan penangguhan. Sehingga secara implisit Penjelasan Pasal 90 ayat (2) tersebut memberikan ruang kepada pengusaha untuk tidak melakukan pembayaran dan kekurangan upah selama jangka waktu tertentu. Hal ini tidak sejalan dengan ketentuan Pasal 28D ayat (2) UUD NRI 1945 yang memberikan perlindungan terhadap pekerja. 
Sehingga perlu dipertanyakan apakah ketentuan dalam Pasal 90 ayat (1) dan Pasal 90 Ayat (2) UU Ketenagakerjaan memang penetapan penangguhan pembayaran upah ini dapat benar-benar memberikan perlindungan terhadap pekerja. Ketentuan yang tidak mewajibkan perusahaan membayar upah minimum yang berlaku saat penangguhan pada akhirnya disalahgunakan oleh perusahaan untuk tidak membayar sisa upah yang belum terbayarkan pada saat penangguhan upah yang seharusnya merupakan upah terhutang. ${ }^{10}$

Berdasarkan problematika tersebut merujuk pada ketentuan Pasal 185 ayat (1) dan ayat (2) UU Ketenagakerjaan secara ekplisit melarang pembayaran upah dibawah upah minimum yang mana tindakan tersebut termasuk ke dalam tindak pidana kejahatan dengan ancaman pidana penjara dan/denda, secara eksplisit memberikan pertimbangan bahwa pembayaran upah minimum oleh pengusaha adalah keharusan dan tidak dapat dikurangi. Sehingga ketentuan Pasal 90 ayat (2) UU Ketenagakerjaan tidak serta merta menghilangkan kewajiban pengusaha dengan kata lain membayar selisih upah minimum dengan pembayaran yang dilakukan pengusaha tersebut selama masa penangguhan merupakan hutang pengusaha yang wajib dibayar kepada pekerja. Hal ini sesuai dengan Putusan Mahkamah Konstitusi Nomor : 72/PUU-XIII/2015.

\section{Penutup}

\subsection{Kesimpulan}

1. Hubungan hukum antara pekerja dan pengusaha adalah hubungan hukum timbal balik yang berupa

10 Ardatha, T. (2017).IMPLIKASI YURIDIS PUTUSAN MAHKAMAH KONSTITUSI NOMOR 72/PUU-XIII/2015 TERHADAP PEMBAYARAN IURAN JAMINAN SOSIAL KETENAGAKERJAAN PADA MASA PENANGGUHAN. Kumpulan Jurnal Mahasiswa Fakultas Hukum. 
hubungan kerja berdasarkan perjanjian yang telah disepakati oleh para pihak (pengusaha dan pekerja) yang mana hubungan tersebut mengandung hak dan kewajiban yang harus dipenuhi oleh para pihak.

2. Penangguhan pembayaran upah mininum tidak menghilangkan kewajiban pengusaha untuk membayar selisih upah minimum selama masa penangguhan sesuai dengan putusan MK No.72/PUU-XIII/2015.

\subsection{Saran}

1. Lembaga Legislasi harus meninjau kembali ketentuan Pasal 90 ayat (1) dan (2) Undang-Undang Nomor 13 Tahun 2003 tentang Ketenagakerjaan mengenai kewajiban Pengusaha dalam penangguhan pembayaran upah minimum pekerja agar sesuai dengan putusan MK No.72/PUU-XIII/2015.

2. Pengusaha harus melakukan pembayaran upah minimum pekerja yang tertangguh dan selisih upah minimum selama masa penangguhan.

\section{Daftar Pustaka}

\section{Buku}

Asyhadie, Zaeni, 2007, Hukum Ketenagakerjaan Bidang Hubungan Kerja, PT. Raja Grafindo Persada, Jakarta.

Fahrojih, Ikhwan, 2016, Hukum Perburuhan, Setara Press, Jawa Timur.

Ibrahim, Johnny, 2015, Teori dan Metode Penelitian Hukum Normatif, Banyumedia Publishing, Malang.

I Made Udiana, 2016, Kedudukan dan Kewenangan Pengadilan Hubungan Industrial, Udayana University Press, Denpasar. 
I Made Udiana, 2011, Rekonstruksi Pengaturan Penyelesaian Sengketa Penanaman Modal Asing, Udayana University Press, Denpasar,

Kartas apoetra, 1994, Hu kum Perburuhan di Indonesia

Berdasarkan Pancasila, Sinar Grafika, Jakarta.

Marzuki, Peter Mahmud, 2015, Penelitian Hukum, Kencana

Prenadamedia Group, Jakarta.

Muham mad, Abdulkadir, 2014, Hukum dan Penelitian Hukum, PT. Citra Aditya Bakti, Jakarta.

\section{Jurnal}

Fenny Natalia Khoe, 2013, "Hak Pekerja Yang Sudah Bekerja

Namun Mendatangi Perjanjian Kerja Atas Upah Ditinjau

Berdasarkan Undang-Undang Nomor 13 Tahun 2003 Tentang Ketenagakerjaan", Jurnal Fakultas Hukum Universitas Surabaya, Surabaya.

Ardatha,T.(2017).IMPLIKASI YURIDIS PUTUSAN MAHKAMAH KONSTITUSI NOMOR 72/PUU-XIII/2015 TERHADAP PEMBAYARAN IURAN JAMINAN SOSIAL KETENAGAKERJAAN PADA MASA PENANGGUHAN. Kumpulan Jurnal Mahasiswa Fakultas Hukum.

Henny Damaryanti,2017, "Pemenuhan Upah Minimum Sebagai Upaya Perlindungan Hak Konstitusional", Jurnal Fakultas Hukum Universitas Panca Bhakti,Pontianak.

\section{Peraturan Perundang-Undangan}

Undang-Undang Dasar Negara Republik Indonesia Tahun 1945

Undang-Undang Republik Indo nesia Nomor 13 Tahun 2003 tentang Ketenagakerjaan (Lembaran Negara Republik Indonesia Tahun 2003 Nomor 39, Tambahan Lembaran Negara Republik Indon esia Nomor 4279) 